\title{
GROWTH OF BACTERIA IN ENTERAL FEEDING SOLUTIONS
}

\author{
ANNETTE ANDERTON* \\ Department of Microbiology, University of Glasgow, Glasgow, G61 1QH \\ Summary. Solutions of Clinifeed ISO, Triosorbon, Vivonex Standard \\ (full- and half-strength) and Vivonex HN were experimentally contami- \\ nated with two strains each of Staphylococcus aureus, Pseudomonas \\ aeruginosa, Klebsiella aerogenes, Escherichia coli and Enterobacter \\ cloacae at concentrations of $10^{2}-10^{3}$ organisms $/ \mathrm{ml}$. Samples were \\ incubated at 4,25 or $37^{\circ} \mathrm{C}$ and viable counts were made at $0,4,8$ and $24 \mathrm{~h}$. \\ No increase in numbers of any of the organisms was observed in any \\ of the feeds during $24 \mathrm{~h}$ at $4^{\circ} \mathrm{C}$. All organisms multiplied rapidly in \\ Clinifeed ISO and in Triosorbon at 25 and $37^{\circ} \mathrm{C}$. There was less rapid \\ growth in half-strength Vivonex Standard at $25^{\circ} \mathrm{C}$, although at $37^{\circ} \mathrm{C}$ all \\ strains multiplied rapidly except for the two $S$. aureus strains, the growth \\ of which was inhibited in half-strength Vivonex Standard at both 25 and \\ $37^{\circ} \mathrm{C}$. In full-strength Vivonex Standard at $25^{\circ} \mathrm{C}$, only $P$. aeruginosa \\ showed any increase in numbers during $24 \mathrm{~h}$, whereas $P$. aeruginosa, $K$. \\ aerogenes and $E$. cloacae all multiplied at $37^{\circ} \mathrm{C}$. None of the test \\ organisms multiplied in full strength Vivonex $\mathrm{HN}$ at any of the \\ temperatures studied. \\ The results of the study show that bacteria survive and may multiply \\ even in feeds with low $p \mathrm{H}$ and high osmolarity, and emphasise the \\ importance of strict hygiene during the preparation and handling of all \\ enteral feeds.
}

\section{INTRODUCTION}

The rapid multiplication of microorganisms in enteral feeds has been reported by several authors (White et al., 1979, Furtado et al., 1980; Simmons, 1981; Bastow et al., 1982; Gibbs, 1983; Anderton, 1984). However, both Furtado et al. (1980) and Stanek et al. (1983) demonstrated that not all enteral feeds support microbial growth. Stanek et al. (1983) reported that when samples of an elemental diet were artificially contaminated with Staphylococcus aureus, Salmonella enteritidis, Yersinia enterocolitica, Pseudomonas aeruginosa, Campylobacter jejuni, Candida albicans or C. tropicalis (all at a concentration of $10^{2}$ organisms $/ \mathrm{ml}$ ) and incubated at $22^{\circ} \mathrm{C}$ for $24 \mathrm{~h}$, only $P$.

Received 2 Jul. 1984; accepted 31 Oct. 1984.

* Present Address: Department of Applied and Life Sciences, The Queen's College, 1 Park Drive, Glasgow G3 6LP. 
aeruginosa and the Candida spp. showed any growth; the numbers of the other species either remained constant or, in the case of Camp. jejuni was reduced. Furtado et al. (1980) also reported that in full strength Vivonex HN, S. aureus and S. epidermidis remained viable but did not proliferate and that neither $P$. aeruginosa nor group-B streptococci survived when incubated at $37^{\circ} \mathrm{C}$ for $24 \mathrm{~h}$.

This study was undertaken to compare the rates of growth of various common bacterial contaminants (Anderton, 1983) in several commercially available enteral feeds.

\section{MATERIALS AND METHODS}

Feeds. The feeds used were: Clinifeed ISO, a UHT-processed, low residue, milk-based, complete liquid feed (Roussel Laboratories Ltd, Wembley Park, London); Triosorbon, a dried, low residue, whole protein, lactose-free feed (E. Merck Ltd, Alton, Hants); Vivonex Standard, a dried, elemental, minimal residue preparation (Eaton Laboratories Ltd, Woking, Surrey); and Vivonex HN, a dried, elemental, high nitrogen, minimal residue preparation.

Dried feeds were reconstituted with sterile water. To ensure that there was no variation in the composition of the feed samples used for different bacteria, bulk samples of each feed.were thoroughly mixed in separate sterile 2000 -ml conical flasks for each experiment; a 20 -ml sample removed aseptically and the $p \mathrm{H}$ measured. Portions of the feeds $(100 \mathrm{ml})$ were then transferred to sterile $250-\mathrm{ml}$ conical flasks. The composition, $p \mathrm{H}$ and osmolarity of each of the feeds are shown in the table.

Bacterial strains. Two strains of each of the following species were used: S. aureus (NCTC nos. 10652 and 10657), P. aeruginosa (NCTC nos. 6750 and 10332), Enterobacter cloacae (NCTC nos. 10005 and 8155), Escherichia coli (NCTC nos. 8007 and 8603) and Klebsiella aerogenes (NCTC nos, 8172 and 9997). All strains were grown in Nutrient Broth No. 2 (Oxoid) for $18-24 \mathrm{~h}$ at $37^{\circ} \mathrm{C}$. The bacterial suspensions were then diluted in $0.1 \%$ peptone water (Oxoid) to give a concentration of approximately $10^{4} \mathrm{cfu} / \mathrm{ml}$. This provided the inoculum.

Procedure. Each bacterial inoculum $(1.0 \mathrm{ml})$ was transferred to each of three separate flasks containing $100 \mathrm{ml}$ of freshly prepared feed, to give an initial count of $10^{2}-10^{3} \mathrm{cfu} / \mathrm{ml}$ of feed (Bastow et al., 1982). After careful mixing a viable count was made on a sample of feed from each flask. Flasks were then incubated at 4,25 or $37^{\circ} \mathrm{C}$, and samples taken for viable counts at 4,8 and $24 \mathrm{~h}$. These temperatures were selected to represent the temperatures at which the feeds would be held in normal practice, i.e., refrigerator temperature, ambient (ward) temperature and the patients' body temperature.

Viable counts were made on serial tenfold dilutions of each sample in $0.1 \%$ peptone water;

\section{TABLE I}

Composition, $\mathrm{pH}$ and osmolarity of enteral feeds diluted to strengths suitable for administration to patients (Values given are those quoted by the manufacturer except for $p H$, which was determined experimentally)

\begin{tabular}{|c|c|c|c|c|c|c|c|}
\hline \multirow[b]{2}{*}{ Feed } & \multicolumn{4}{|c|}{ Composition $(\mathrm{g} / 100 \mathrm{ml})$} & \multirow{2}{*}{$\begin{array}{l}\text { Osmolarity } \\
(\mathrm{mosm} / \mathrm{L})\end{array}$} & \multirow[b]{2}{*}{$p \mathrm{H}$} & \multirow[b]{2}{*}{ Preparation of feed } \\
\hline & Protein & Amino acids & Carbohydrate & Fat & & & \\
\hline Clinifeed ISO & $2 \cdot 8$ & $\ldots$ & $13 \cdot 1$ & $4 \cdot 1$ & 270 & 6.8 & Liquid, no dilution \\
\hline Triosorbon & $4 \cdot 0$ & $\ldots$ & 11.9 & 4.0 & 238 & 6.9 & 1 sachet of powder and \\
\hline \multirow{3}{*}{$\begin{array}{l}\text { Vivonex Standard } \\
\text { (full-strength) } \\
\text { Vivonex Standard } \\
\text { (half-strength) } \\
\text { Vivonex HN }\end{array}$} & $\ldots$ & 2.06 & $23 \cdot 0$ & $0 \cdot 15$ & 550 & $5 \cdot 4$ & \multirow{3}{*}{$\begin{array}{l}\text { 1 sachet of powder and } \\
\text { water to volume of } 300 \mathrm{ml} \\
\text { 1 sachet of powder and } \\
\text { water to volume of } 600 \mathrm{ml} \\
\text { I sachet of powder and } \\
\text { water to volume of } 300 \mathrm{ml}\end{array}$} \\
\hline & $\ldots$ & 1.03 & $11 \cdot 5$ & $0 \cdot 08$ & 265 & $5 \cdot 4$ & \\
\hline & $\ldots$ & $4 \cdot 44$ & $21 \cdot 10$ & 0.09 & 800 & $4 \cdot 4$ & \\
\hline
\end{tabular}


$0.1 \mathrm{ml}$ of each dilution was spread over the surface of pre-dried plates of Plate Count Agar (PCA; Oxoid). The plates were then incubated aerobically at $37^{\circ} \mathrm{C}$ for $24 \mathrm{~h}$. Counts were made in triplicate and the mean count expressed as $\mathrm{cfu} / \mathrm{ml}$. The experiment was repeated three times.

Control samples of uninoculated feeds were examined simultaneously.

\section{RESULTS}

The two strains of each bacterial species grew at similar rates in all experiments and the results given are the average counts obtained. The results for all feeds except Triosorbon are presented in the figure. No organisms were detected in the control flasks of Clinifeed ISO, Vivonex Standard (full- and half-strength) or Vivonex HN. In each of the three experiments, the control flasks of Triosorbon were found to be contaminated with aerobic sporeforming bacilli; the counts increased during $8 \mathrm{~h}$ from undetectable to $10^{1} \mathrm{cfu} / \mathrm{ml}$ at $25^{\circ} \mathrm{C}$ and $10^{2} \mathrm{cfu} / \mathrm{ml}$ at $37^{\circ} \mathrm{C}$. After $24 \mathrm{~h}$ counts had risen to $10^{7}$ and $10^{9} \mathrm{cfu} / \mathrm{ml}$ at 25 and $37^{\circ} \mathrm{C}$ respectively.

All test organisms multiplied rapidly in Clinifeed ISO and Triosorbon; the counts increased during $8 \mathrm{~h}$ from $10^{2}-10^{3}$ to $10^{4}-10^{5} \mathrm{cfu} / \mathrm{ml}$ at $25^{\circ} \mathrm{C}$ and to $10^{5}-10^{6} \mathrm{cfu} / \mathrm{ml}$ at

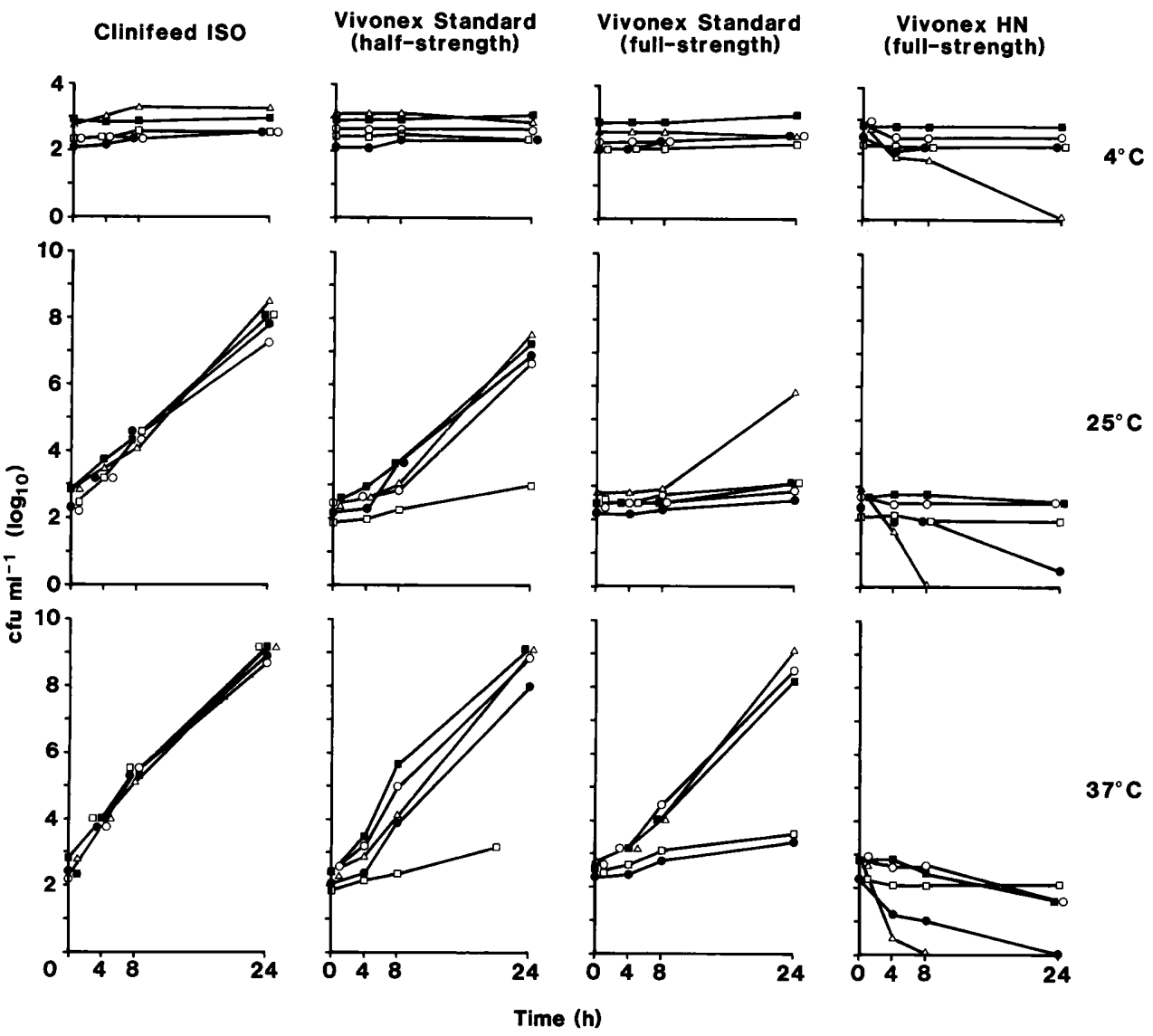

Fig. 1.-Growth of various species of bacteria in Clinifeed ISO, Vivonex and Vivonex $\mathrm{HN}$ at 4,25 and $37^{\circ} \mathrm{C}$. E. cloacae $\square$; $P$. aeruginosa $\triangle \longrightarrow \Delta ; K$. aerogenes $O \longrightarrow O$; S. aureus $\square-\square$; and Esch. coli 
$37^{\circ} \mathrm{C}$, although it was difficult to make accurate counts of the numbers of test organisms in Triosorbon because of the growth of contaminants and 24-h viable counts were not made in this feed. After $24 \mathrm{~h}$, counts in Clinifeed ISO were $10^{7}-10^{9}$ and $10^{8}-10^{10} \mathrm{cfu} / \mathrm{ml}$ at 25 and $37^{\circ} \mathrm{C}$ respectively.

At $37^{\circ} \mathrm{C}$, the rate of growth of $E$. cloacae and $K$. aerogenes strains in half-strength Vivonex Standard was similar to that in Clinifeed ISO. Growth of Esch. coli and $P$. aeruginosa in half-strength Vivonex was slightly inhibited initially, only reaching $10^{4}$ $\mathrm{cfu} / \mathrm{ml}$ after $8 \mathrm{~h}$. However, growth was then more rapid, reaching $10^{8}$ and $10^{9} \mathrm{cfu} / \mathrm{ml}$ respectively after $24 \mathrm{~h}$. Half-strength Vivonex inhibited the growth of both strains of $S$. aureus at 25 and $37^{\circ} \mathrm{C}$; there was very little increase in numbers after $8 \mathrm{~h}$ and the final count at both temperatures was only $10^{3} \mathrm{cfu} / \mathrm{ml}$. Growth of the remaining test organisms was slower at $25^{\circ} \mathrm{C}$ in half-strength Vivonex than in Clinifeed ISO; counts after $8 \mathrm{~h}$ were in the range $10^{3}-10^{4} \mathrm{cfu} / \mathrm{ml}$ and those at $24 \mathrm{~h}$ in the range $10^{6}-10^{8} \mathrm{cfu} / \mathrm{ml}$.

In full-strength Vivonex Standard the growth of all the test organisms was inhibited at $25^{\circ} \mathrm{C}$; there was no increase in numbers after $8 \mathrm{~h}$ or $24 \mathrm{~h}$ with the exception of $P$. aeruginosa which showed an increase in numbers from $10^{3}$ to $10^{6} \mathrm{cfu} / \mathrm{ml}$ between 8 and $24 \mathrm{~h}$. S. aureus and Esch. coli were also inhibited at $37^{\circ} \mathrm{C}$; numbers only increased from $10^{2}$ to $10^{3}-10^{5} \mathrm{cfu} / \mathrm{ml}$ in $24 \mathrm{~h}$. However, $P$. aeruginosa, $K$. aerogenes and $E$. cloacae multiplied to give counts of $10^{4}-10^{5}$ after $8 \mathrm{~h}$ and $10^{8}-10^{9} \mathrm{cfu} / \mathrm{ml}$ after $24 \mathrm{~h}$.

None of the test organisms multiplied in full strength Vivonex HN. Counts of both strains of $P$. aeruginosa decreased from $10^{2}$ to $10^{1} \mathrm{cfu} / \mathrm{ml}$ at all three temperatures after $4 \mathrm{~h}$. Counts remained at this level after $8 \mathrm{~h}$ at $4^{\circ} \mathrm{C}$ but after $8 \mathrm{~h}$ at $25^{\circ} \mathrm{C}$ and $37^{\circ} \mathrm{C}$ and after $24 \mathrm{~h}$ at $4^{\circ} \mathrm{C}$, no organisms were detectable. There was no change in the numbers of $S$. aureus during $24 \mathrm{~h}$, counts remaining at $10^{2} \mathrm{cfu} / \mathrm{ml}$ at 4,25 and $37^{\circ} \mathrm{C}$. Esch. coli survived for $24 \mathrm{~h}$ at $4^{\circ} \mathrm{C}$ but numbers decreased from $10^{2}$ to $10^{1} \mathrm{cfu} / \mathrm{ml}$ after $8 \mathrm{~h}$ and to undetectable levels after $24 \mathrm{~h}$ at 25 and $37^{\circ} \mathrm{C}$. Strains of $K$. aerogenes and $E$. cloacae survived for $24 \mathrm{~h}$ at $4^{\circ}$ and $25^{\circ} \mathrm{C}$, but numbers decreased from $10^{2}$ to $10^{1} \mathrm{cfu} / \mathrm{ml}$ after $24 \mathrm{~h}$.

\section{Discussion}

The susceptibility of patients fed by the naso-gastric or naso-enteric route to colonisation and infection by microorganisms present in the feeds has been discussed by Casewell (1982) and Anderton (1983). The number of organisms that must be ingested by a patient for colonisation of the intestine to occur will vary according to the patient's treatment and the underlying disease. Pottecher et al. (1979) suggested that $10^{4}$ organisms $/ \mathrm{ml}$ of feed are sufficient to colonise the digestive tract of hospital patients but, more recently, in a discussion of the role of salads as a source of potential pathogens, Remington and Schimpff (1981) stated that 'for the patient with reduced resistance to colonisation due to the systemic administration of antimicrobials, $1 \mathrm{~g}$ of salad with $10^{3}$ gram-negative rods is probably sufficient to lead to persistent colonisation of the intestinal tract'.

Multiplication of all the test organisms to numbers in excess of $10^{4} \mathrm{cfu} / \mathrm{ml}$ of feed within $8 \mathrm{~h}$ was observed at 25 and $37^{\circ} \mathrm{C}$ in Clinifeed ISO and Triosorbon. Similar results have been reported by Furtado et al. (1980) and Simmons (1981) in studies on the multiplication of bacteria in Osmolite and a Complan-based home-made feed.

The counts of all the test strains in all the feeds remained fairly constant at $10^{2}-10^{3}$ 
$\mathrm{cfu} / \mathrm{ml}$ during $24 \mathrm{~h}$ at $4^{\circ} \mathrm{C}$, and comparison of these figures with those recorded at $25^{\circ} \mathrm{C}$ demonstrate the importance of storing prepared feeds in a refrigerator.

Half-strength Vivonex was also an excellent growth medium for the test strains, with the exception of $S$. aureus; counts after 8 and $24 \mathrm{~h}$ at 25 and $37^{\circ} \mathrm{C}$ were only slightly less than those in Clinifeed ISO, possibly because of the lower $p \mathrm{H}(5 \cdot 5)$ of Vivonex. The noticeable inhibition of $S$. aureus might be explained by the low $p \mathrm{H}$, the high concentration of glucose solids and the presence of sorbate and acetate in the formulation. Schmidt et al. (1969) found that sorbate $1 \mathrm{mg} / \mathrm{g}$ prevented the growth of $S$. aureus in artificial cream pies acidified to $p \mathrm{H} 4 \cdot 5-5 \cdot 0$. Vivonex has a $p \mathrm{H}$ of $5 \cdot 5$ and at half-strength contains sorbate $0.25 \mathrm{mg} / \mathrm{ml}$. Zacherle and Charache (1970), in a study of peritoneal dialysis solutions, found that the factors associated with the inhibition of $S$. aureus were low $p \mathrm{H}$ and the presence of acetate and dextrose; maximum inhibition was caused by a combination of all three factors.

The lack of growth of all the test organisms at $25^{\circ} \mathrm{C}$ in full-strength Vivonex during the first $8 \mathrm{~h}$ of the study was probably due to a combination of low $p \mathrm{H}$, high osmolarity and an incubation temperature below the optimum for these organisms. The increase in numbers of $P$. aeruginosa from $10^{3}$ to $10^{6} \mathrm{cfu} / \mathrm{ml}$ between 8 and $24 \mathrm{~h}$ reflects this organism's tolerance of inhospitable growth conditions. At $37^{\circ} \mathrm{C}, P$. aeruginosa, $K$. aerogenes and $E$. cloacae grew well in full-strength Vivonex despite the low $p \mathrm{H}$ and high osmolarity of the product, whereas $S$. aureus and $E$. coli showed little growth.

The failure of all organisms to grow in full stength Vivonex $\mathrm{HN}$ can be attributed to the high osmolarity of this feed $(800 \mathrm{mosm} / \mathrm{L})$. Similar results were reported by Furtado et al. (1980) and Hostetler et al. (1982). Stanek et al. (1983) showed that the growth of various bacterial strains was inhibited in an elemental diet with an osmolarity of $580 \mathrm{mosm} / \mathrm{L}$.

The presence of aerobic sporeforming bacilli as contaminants in Triosorbon and their rapid multiplication at 25 and $37^{\circ} \mathrm{C}$ is of concern since Gilbert et al. (1981) suggested that several Bacillus spp. can cause opportunistic infections in compromised hosts and that some may also be capable of causing food poisoning. Bastow et al. (1982) reported the presence of aerobic sporeforming organisms (including $B$. cereus) in Complan, another dried product used in enteral feeds. Therefore, it should not be assumed that all the proprietory products available for use in the formulation of enteral feeds are sterile and it would be advisable to ascertain the microbiological quality of all batches of dried products before use.

The results of this study emphasise the importance of strict microbiological quality control of ingredients and stringent hygienic precautions during the preparation and handling of all enteral feeds because bacteria can survive and multiply in feeds with low $p \mathrm{H}$ and high osmolarity, as well as in neutral, isotonic feeds.

I thank Professor A.C. Wardlaw and Dr R. Parton, Microbiology Department, Glasgow University, for critically reading the manuscript.

\section{REFERENCES}

Anderton A 1983 Microbiological aspects of the preparation and administration of naso-gastric and naso-enteric tube feeds in hospitals-A review. Human Nutrition: Applied Nutrition 37A:426-440.

Anderton A 1984 The potential of Escherichia coli in enteral feeds to cause food poisoning:a study under simulated ward conditions. Journal of Hospital Infection 5:155-163. 
Bastow M D, Greaves P, Allison S P 1982 Microbial contamination of enteral feeds. Human Nutrition: Applied Nutrition 36A:213-217.

Casewell M W 1982 Bacteriological hazards of contaminated enteral feeds. Journal of Hospital Infection 3:329-331.

Furtado D, Parrish A, Beyer P 1980 Enteral nutrient solutions (ENS): in vitro growth supporting properties of ENS for bacteria. Journal of Parenteral and Enteral Nutrition 4:594.

Gibbs J 1983 Bacterial contamination of naso-gastric feeds. Nursing Times 79(7): 41-47.

Gilbert R J, Turnbull P C B, Parry J M, Kramer J M 1981 Bacillus cereus and other Bacillus species:their art in food poisoning and other clinical infections. In: Berkeley $\mathrm{R} \mathrm{C} \mathrm{W}$, Goodfellow M (eds) The aerobic endospore-forming bacteria:classification and identification. Society for General Microbiology Special Publications Series No. 4. Academic Press, London, pp 297-314.

Hostetler C, Lipman T O, Geraghty M, Parker R H 1982 Bacterial safety of reconstituted continuous drip tube feeding. Journal of Parenteral and Enteral Nutrition 6:232-235.

Pottecher B, Goetz M L, Jacquemaire M A, Reeb, E, Lavillaureix J 1979 Entérocolites infectieuses chez des malades de réanimation alimentés par sonde naso-gastrique. Annales de l'Anesthesiologie Francaise 20:595-602.

Remington J S, Schimpff S C 1981 Please don't eat the salads. New England Journal of Medicine 304:433-435.

Schmidt E W, Gould W A, Weiser H H 1969 Chemical preservatives to inhibit the growth of Staphylococcus aureus in synthetic cream pies acidified to $\mathrm{pH} 4.5$ to $5 \cdot 0$. Food Technology 23:1197-1220.

Simmons N A 1981 Hazards of naso-enteric feeds. Journal of Hospital Infection 2:276-278.

Stanek G, Hirschl A, Lochs H, Egger T P 1983 Growth of various bacteria and yeasts in a peptide and an elemental diet. Journal of Hospital Infection 4:51-56.

White W T, Acuff T E, Sykes T R, Dobbie R P 1979 Bacterial contamination of enteral nutrient solution: a preliminary report. Journal of Parenteral and Enteral Nutrition 3:459-461.

Zacherle B J, Charache P 1970 Microbiologic properties of the peritoneal dialysate solutions: Clinical Research 18:448. 